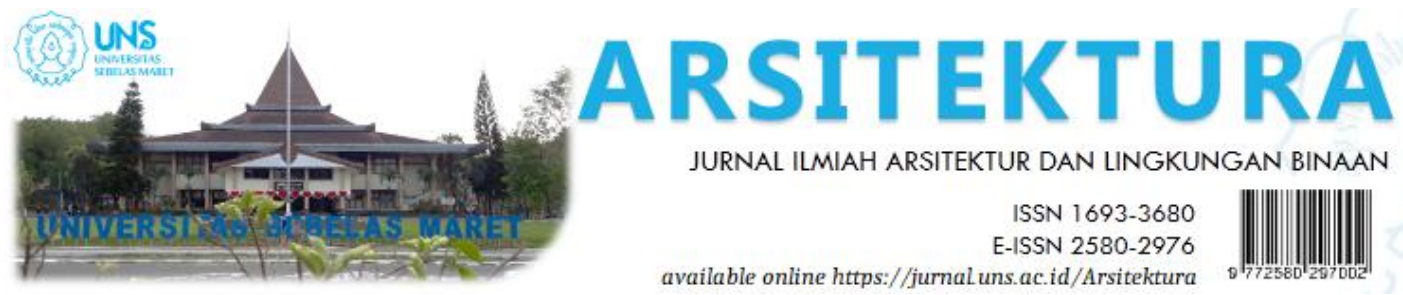

Volume 19 Issue 1 April 2021, pages:63-74

\title{
Ke-Kriya-an pada Arsitektur Jawa
}

\section{Craft in Javanese Architecture}

\author{
Hardiyati $^{1 *}$, Anita Dianingrum ${ }^{2}$ \\ Department Architecture, Faculty of En gineering Universitas Sebelas Maret ${ }^{1 *}$ \\ hardiyati@staff.uns.ac.id \\ Department Architecture, Faculty of Engineering Universitas Sebelas Maret ${ }^{2}$
}

DOI: https://doi.org/10.20961/arst.v19i1.45998

Received: November 26,2020 Revised: April 11,2021 Accepted: April 18,2021 Available online: April 30,2021

\begin{abstract}
Development of unlimited information resulting in the loss of the diversity of architecturalidentity of place. Contemporary architecture develops without control and without clear concept seeds. Craftsmanship is always attached to art because in the final result there is a content of art, even though the meaning of art is always being discussed and always developing. Javanese house architecture has three important things, namely the relationship of Jiwa Cipta /wastu, resources/kalang and form/wewangunan, which are the totality of architecture. The purpose of this research is to describe the understanding of "Javanese architecture" by taking a broader perspective that will be used in this study. This relationship will be traced through the craftsmanship inherent in Javanese architectural works. The method used is field research which is a qualitative research with problems in a natural setting to interpret and interpret the observed phenomena. Craftsmanship of Javanese architectural will complement the knowledge of Javanese architecture which will enrich the identity of Indonesian architecture in accordance with the place and time travel which will always change according to human civilization. Craftsmanship in Javanese architecture produce Javanese architecture consisting of constructive and non-constructive percussion crafts that are able to provide articulation of the manufacturing process, articulation of talent/ character of materials, articulation of expression ofload joints articulation of material processing.
\end{abstract}

Keywords: craft, craftsmanship, Javanese Architecture

\section{PENDAHULUAN}

Karya arsitektur selalu berhubungan dengan gerak daya hidup seluruh kegiatan manusia sebagai insan yang mewujudkan. Perilaku gerak daya hidup manusia secara alami adalah memiliki kebebasan, bagaikan bebas luasnya alam semesta yang ditempatinya. Arsitektur hampir selalu berkaitan dengan lingkungan buatan yang merupakan lingkungan yang tercipta untuk ruang perteduhan.
Kriya ketukangan merupakan sebuah kerja kerajinan tangan. Kriya ketukangan adalah sesuatu yang dihadirkan atau dibuat dengan tangan dan sering sebagai barang guna, proses pembuatannya biasanya dengan menggunakan berbagai alat dan pembuatnya sangat menguasai alat tersebut dan memahaminya. Proses kriya pada rumah jawa kental dengan kerja ketukangan yang akan mengindahkan tata cara teknis yang benar yaitu bagaimana menentukan bahan, teknik pengerjaan sesuai 
dengan wujud yang akan dicapai dan diinginkan.

Arsitektur jawa adalah Arsitektur pernaungan (Prijotomo, 2006), dengan demikian seorang penghuni selalu dekat dengan lingkungan sekitarnya, dimana selalu ada perasaan besatu dengan alam. Ruangan bagi tindakan bernaung didapatkan keberadaannya dari komponen utama bangunan berupa penaung atau peneduh. Daerah yang ternaungi kemudian menjadi volume ruangan sehingga bernaung dapat dilakukan dan kemudian kegiatan sehari-hari dibawahnya dapat dilakukan. Dari uraian tersebut payon atau atap menjadi penting. sehingga sering kita saksikan Arsitektur jawa atap atau payon menjadi sangat penting dan dominan.

Arsitektur yang ada di Indonesia termasuk arsitektur jawa didalamnya bisa disebut "the architectural unconscious." yaitu: "ketukangan". Mengikuti Richard Sennett (2008) dalam The Craftsman, "ketukangan", ditandai oleh komitmen untuk mengerjakan sesuatu sebaik-baiknya. "Ketukangan", bahkan juga "seni" (fine arts) dan juga arsitektur, merupakan hibriditas antara berbagai jenis kerja - tetapi tetap dengan dasar "kesadaran material". Kesadaran material, atau "material conciousness" adalah kesadaran bekerja "melalui" dan "dengan" perkakas yang ada pada kita. Artinya kepekaan kepada tenaga manusia, bahan, lingkungan alam, dan semua yang kongkrit, berubah, dan majemuk (IAI, 2014).

Arsitektur rumah Jawa memiliki tiga hal penting yaitu relasi Jiwa cipta /wastu, sumberdaya/kalang dan wujud/wewangunan (Ronald,2005), yang ketiganya merupakan totalitas arsitektur. Ada empat wujud dalam arsitetur jawa yang lazim dikenali yaitu bentuk joglo, limasan, kampong dan bentuk tajuk. Konstruksi didominasi konstruksi kayu . Naluri bangunan arsitektur jawa untuk mempertahankan diri terhadap lingkungan diungkap pada struktur konstruksi yang mudah dibongkar pasang, mereka mudah memindahkan rumah ke tempat lain apabila tidak cocok dengan suatu keadaan.

Kriya ketukangan berfokus pada tangan sebagai alat untuk membuat makna. Tangan memungkinkan untuk belajar, memikirkan, "memegang", "merasakan" hal-hal yang sedang dilakukan (Sennett,2008). Metafora ini kemudian diperluas untuk memikirkan metafora prosedural untuk belajar atau memperoleh pengetahuan atau keterampilanmereka belajar dengan melakukan". Metafora ini menunjukkan hubungan antara kepala dan tangan, yang kemudian hilang dalam metafora hafalan, pengulangan, dan mekanisasi dalam pembelajaran. memperluas hubungan antara tangan dan kepala/pikiran sebagai proses membuat sesuatu secara total. Dari karya arsitektur jawa yang kita kenali akan terlihat didominasi karya kriya ketukangan yang dikhawatirkan akan punah karena dimakan waktu dan kemoderan. Sehingga kita perlu menganyam kembali dari serpihan-serpihan pengetahuan lokal yang masih ada dan masih bisa dikenali.

\section{METODE}

Penelitian ini mengarah pada penemuan karakteristik Ke-kriyaan arsitektur Jawa. Metoda yang digunakan pada penelitian ini adalah metode kualitatif field research dimana akan melihat permasalahan dalam setting yang natural dalam upaya untuk memaknai, menginterpretasi fenomena yang teramati (Groat \& Wang, 2002) dengan observasi lapangan dan indepth interview untuk melakukan pemetaan fisik dan non fisik sebagai bahan analisis untuk menemukan karakteristik ke-kriyaan arsitektur jawa (Groat \& Wang, 2002). Ada empat komponen kunci berkaitan dengan penelitian ini yaitu penekanan pada setting natural, peneliti menerapkan berbagai taktik untuk menempatkan diri dalam konteks penelitiannya; fokus pada interpretasi dan makna, peneliti memainkan peran penting dalam menginterpretasi dan memaknai data dan fokus pada memaknai keadaan apa adanya Tujuan dari peneliti adalah mempresentasikan gambaran menyeluruh dari setting atau fenomena lapangan. 


\section{HASIL DAN PEMBAHASAN}

\subsection{Gambaran tentang Arsitektur Jawa}

Karya arsitektur selalu berhubungan dengan gerak daya hidup seluruh kegiatan manusia sebagai insan yang mewujudkannya. Perilaku gerak daya hidup manusia secara alami adalah memiliki kebebasan, sebagimana bebas luasnya alam semesta yang ditempatinya. Arsitektur hampir selalu berkaitan dengan lingkungan buatan yang merupakan lingkungan yang tercipta untuk ruang perteduhan.

Kriya merupakan sebuah kerja kerajinan tangan. Kriya adalah sesuatu yang dihadirkan atau dibuat dengan tangan dan sering sebagai barang guna, dalam proses pembuatannya biasanya dengan menggunakan berbagai alat dan pembuatnya sangat menguasai alat tersebut dan memahaminya. Proses kriya pada rumah jawa kental dengan kerja ketukangan yang akan mengindahkan tata cara teknis yang benar yaitu bagaimana menentukan bahan, Teknik pengerjaan sesuai dengan wujud yang akan dicapai dan diinginka.

Arsitektur jawa adalah Arsitektur pernaungan (Prijotomo, 2006), dengan demikian seorang penghuni selalu dekat dengan lingkungan sekitarnya, perasaan besatu dengan alam selalu diperoleh. Ruangan bagi tindakan bernaung didapatkan keberadaannya dari komponen utama bangunan berupa penaung atau peneduh. Daerah yang ternaungi kemudian menjadi volume ruangan sehingga bernaung dapat dilakukan dan kemudian kegiatan sehari-hari dibawahnya dapat dilakukan. Dari uraian tersebut payon atau atap menjadi penting. sehingga sering kita saksikan Arsitektur jawa atap atau payon menjadi sangat penting dan dominan.

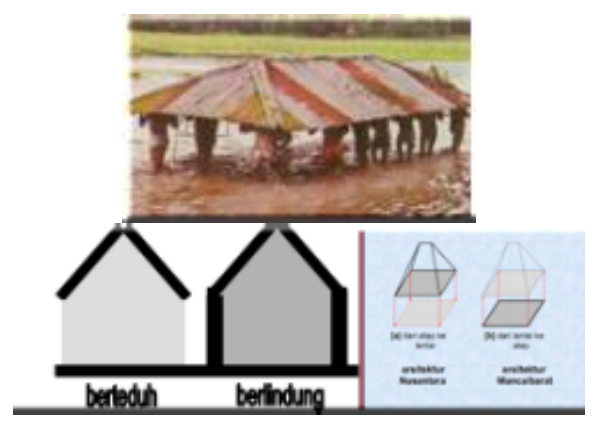

Gambar 1. Ilustrasi konsep berteduh dan berlindung

Sumber: Prijotomo, 2006
Arsitektur rumah Jawa memiliki tiga hal penting yaitu relasi Jiwa cipta /wastu, sumberdaya/kalang dan wujud /wewangunan, yang ketiganya merupakan totalitas arsitektur. Ada empat wujud dalam arsitetur jawa yang lazim dikenali yaitu bentuk joglo, limasan, kampong dan bentuk tajuk. Konstruksi didominasi konstruksi kayu . Naluri bangunan arsitektur jawa untuk mempertahankan diri terhadap lingkungan diungkap pada struktur konstruksi yang mudah dibongkar pasang, mereka mudah memindahkan rumah ke tempat lain apabila tidak cocok dengan suatu keadaan. Dari karya arsitektur jawa yang kita kenali akan terlihat didominasi karya ketukangan yang dikhawatirkan akan punah karena dimakan waktu dan kemoderan. Sehingga kita perlu menganyam kembali dari serpihan-serpihan pengetahuan lokal yang masih ada dan masih bisa dikenali.

\subsection{Membangun, Mendirikan, dan Mengkonstruksi}

Perbincangan ketiga hal tersebut akan terkait dengan ketahanan, beban, tumbuh dan berkembang, pengaruh sekitar,konteks geologi yang menjadi faktor penting. Pengetahuan tentang alam , cuaca, musim dan maklukhidup yang ada disekitarnya. Semua pengetahuan tersebut akan terakumulasi menjadi budaya membangun. Budaya membangun akan terlacak karena bahan yang tersedia, pengetahuan bahan, pengetahuan konstruksi, peralatan, ketrampilan ketukangan nilai rasa.

Manifestasi ke-kriyaan pada arsitektur jawa merupakan perkembangan ketukangan masa lampau yang menjadi jejak sejarah masa lalu, sekarang dan akan datang. Ke- kriya-an pada arsitektur jawa lahir dari aktivitas keseharian, yang bersifat kriya fungsional sebagai pemenuh kebutuhan peralatan rumah tangga, perlengkapan upacara, kebutuhan interioreksterior rumah tinggal, dan lainnya. Aktifitas pembuatan itu biasanya dilakukan pada sela pekerjaan pertanian dan pekerjaan lain. Kekriyaan pada arsitektur jawa masih bisa bertahan dalam bentuk artefak yang perlu dipertahankan yang menjadi pengetahuan aritektur yang terkoneksi dengan berbagai pengetahuan. 


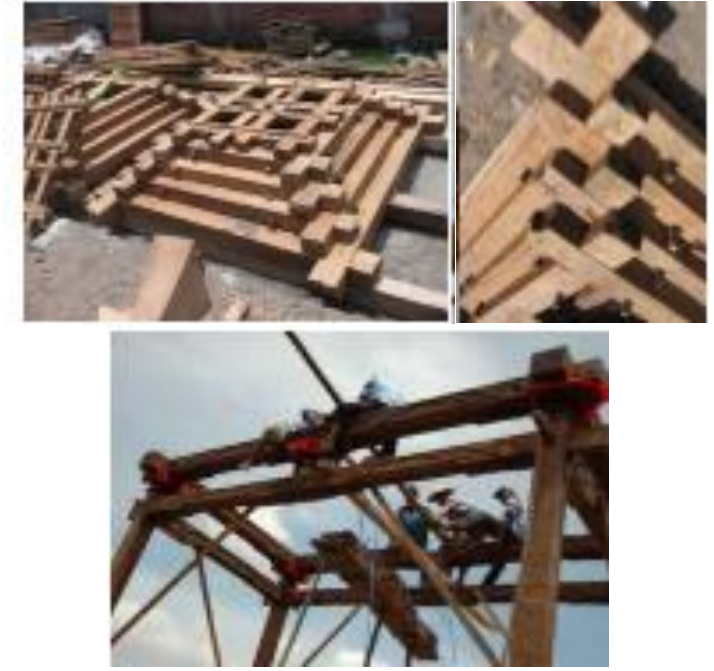

Gambar 2. Elemen konstruksi semua dikerjakan dengan ketukangan tangan dan alat-alat sederhana Sumber: Hardiyati, 2015

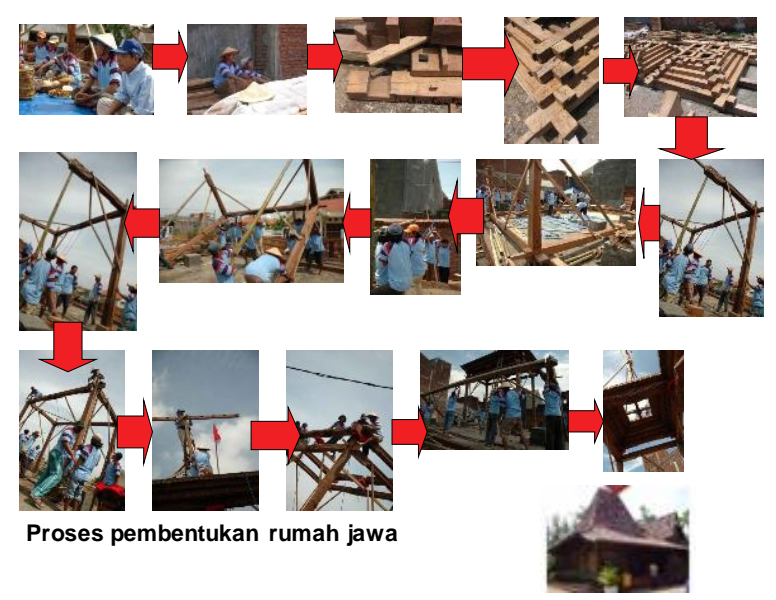

Gambar 3. Proses pembentukan Arsitektur Jawa Sumber: Hardiyati, 2015

Arsitektur jawa yang terlihat wujudnya merupakan bangunan yang bercirikan karya tangan dan tampil dengan kejujuran struktur konstruksinya. Bangunan sebelum didirikan telah disetel dimana setiap elemen punya peran masing-masing dalam rangkaian struktur konstruksi yang terlihat jelas pembuatannya dengan ketrampilan tangan. Disini struktur konstruksipun memberi ruang yang luas untuk nafas karya tangan (craftmanship) yang sebenarnya dikampung-kampung sekarang masih berlangsung.

Dengan demikian membangun bangunan arsitektur jawa berarti akan berurusan dengan mendirikan, menyusun, menegakkan dan biasanya rumah tinggal merupakan awal manusia mendirikan bangunan karena untuk kepentingan bernaung sebelum membangun bangunan yang lain.Pertama ketika mendirikan bangunan ke-kriyaan akan berkaitan dengan kegiatan teknis yaitu mengkonstruksi.

Peran yang dimainkan oleh ketukangan adalah produksi kerajinan bangunan untuk menciptakan ruang arsitektur. Para tukang memiliki bentuk pengetahuan tertentu. Pengerjaan dan desain arsitektur sangat bergantung pada bentuk pengetahuan keterampilan selain pengalaman yang telah dimiliki para tukang si pembuat bangunan jawa. Disamping pengetahuan ketukangan yang dimilikinya dalam mendirikan bangunan juga merupakan sistim pengetahuan yang terdistribusi dari hal yang sifatnya teknis arsitektur ke pengrajin. Kedua hal tersebut penting untuk berhasilnya karya arsitektur bisa terwujud. Dapat dilihat dalam proses membangun rumah jawa proses menjadi sangat penting bagi sang tukang. Para tukang selalu memeriksa antar pekerjaan yang ada dalam keseluruhan yang akan dibangun . Para tukang selalu memiliki cara yang berbeda untuk melalukan pengkontruksian dengan pemikiran yang komprehensif tidak hanya teknis tetapi sampai ke bagaimana tidak menghabiskan material yang tidak perlu atau singkatnya efisien.

Para pembangun biasanya adalah para tukang yang pada awalnya sebagai tukang pada dirinya sendiri, tukang dan ketukangannya craft and craftmansif adalah peran penting pada sebuah kebudayaan yang sering tidak mendapatkan perhatian dan dikecilkan perannya dalam pengetahuan dan praktek arsitektur. Sehingga peran tukang adalah sebuah kesadaran bahwa budaya membangun bermula dari hasrat eksintensial manusia dalam manusia menjalankan aktifitas budaya nya (mahatmanto, 1999).

Para tukang pada pembangun arsitektur jawa memiliki Teknologi arsitektur yang unik dimana para tukang mampu menciptakan ideide metafora yang menempatkan mereka dalam alam melalui manipulasi bentuk dengan mengarahkan potensi alam. Dengan demikian mampu menciptakan teknologi arsitektur menyertakan pembentukan metafora berfikir tentang potensi/kekuatan alam. hal ini akan 
melengkapi bahwa bahwa teknogi ketukangan selalu berorientasi hal yang selalu sifatnya terukur saja tetapi ada sesuatu yang lebih prinsipiil ada sesuatu yang esensi penting dalam lingkungan alam dan mulai memiliki muatan filosofis tentang sesuatu yang unik, spesifik dengan interpretasi yang bermakna pada lingkungan alam binaan.

Setiap penggunaan teknologi pertukangan akan memberi karakter dari yang belajar dari kekuatan alam, manusia pembangun /tukang dan lingkungannya melalui manipulasi dari sesuatu pemikiran contohnya adalah gravitasi adalah bicara sesuatu yang berat atau ringan tetapi telah menjadi tatanan yang hirarkis dari susunan kayu-kayu pada atap rumah. Contoh lain sinar dari matahari bukan hanya berlalunya hari tetapi lebih pada efek khusus yang ditimbulkan dari lubang-lubang dari seluruh rumah yang akan memberi nuansa tertentu.

Setiap manipulasi pada teknologi ketukangan pada arsitektur jawa akan menghadirkan makna simbolik yang beragam. Teknologi ketukangan tak pernah bekerja secara sederhana teknologi ketukangan telah memungkinkan manusia bertahan hidup dibawah naungan tempat tinggalnya sehingga teknologi ketukangan akan bekerja secara tak terbatas yang akan menyentuh sesuatu yang intangible. Sugesti sosial dan faktor budaya merupakan faktor kekuatan penting dalam penciptaan bentuk. Terdapat relasi antara mekanik dan meaning/makna yang indah/rapi. Arsitektur jawa kebanyakan bukan produk arsitek melainkan dirancang oleh orang -orang yang membuat dan tinggal didalamnya. Ini merupakan budaya bertempat tinggal, keterampilan dan pengetahuan yang telah lama hilang pada masyarakat kontemporer. Dalam arsitektur jawa hadir pembelajaran trial and error dengan apa yang dihadapi pada potensi alam disekitarnya yang ditandai dengan teknologi ketukangan tradisional. Sebagai pembelajaran teknik konstruksi semua menjadi dikodekan dalam ritual budaya dalam membuat rumah.

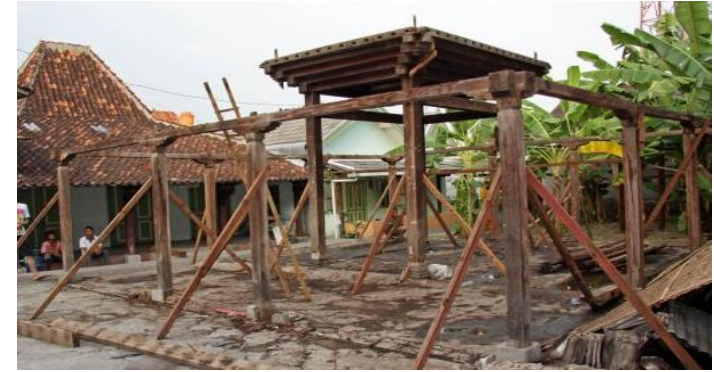

Gambar 4. Gambaran rangka-rangka utama bangunan rumah jawa

Ke-kriya tangan pertukangan merupakan teknologi arsitektur dari sudut pandang lain yang merupakan cara dimana manusia menciptakan ide-ide metafora yang menempatkan mereka dalam alam melalui manipulasi bentuk dengan mengarahkan potensi alam. Dengan demikian kriya ketukangan menyertakan pembentukan metafora berfikir tentang potensi/kekuatan alam. hal ini akan melengkapi bahwa bahwa teknogi selalu berorientasi hal yang selalu sifatnya terukur saja tetapi ada sesuatu yang lebih prinsipiil ada sesuatu yang esensi penting dalam lingkungan alam dan mulai memiliki muatan filosofis tentang sesuatu yang unik, spesifik dengan interpretasi yang bermakna pada lingkungan alam binaan (Vine, 2001).

Dalam menganalisis bentuk teknologi ketukangan pada arsitektur jawa memiliki kemampuan untuk menggunakan material kayu secara hirarkis berdasarkan kepentingan, kayu yang memiliki kekuatan baik biasanya ditempatkan pada peran penyangga berdirinya bangunan yang utama selanjutnya klas berikutnya juga difungsukan untuk hal2 yang paling rendah resikonya dalam menyangga bangunan seperti terlihat pada gambar 4 menunjukan kwalitas material yang paling baik pada daerah pamidangan dimana keempat soko guru berdiri. Ini sebenarnya merupakan sebuah kecerdikan sebuah respon ketukangan dalam mengubah sumber daya alam menjadi bentuk yang bergunan secara manusiawi . Dalam proses ini terdapat kekuatan tangan dan pikiran manusia pembangun yaitu tukang untuk memodifikasi sumber data alam dengan cara yang memungkinkan untuk menjawab masalah yang dihadapi dalam memangun hunian rumah jawa. 
Disamping fungsi struktur-konstruksi karya ketukangan mampu menghadirkan polesan estetika tanpa mengurangi peran elemen bangunan sebagai elemen struktur konstruksi. Beragam susunan kayu menghadirkan komposisi yang menarik dengan ornamen yang ditambahkan yang pada akhirnya akan menghadirkan komposisi yang menarik dan indah.Terlihat pada gambar 5. balok blandar pengeret pada sudut 2 akan tersusun sehingga menyerupai relief karena susunan balok, disamping relief /ornamen yang dihadirkan pada balok saten kecil antara balaok atas dan balok bawah fungsi menyangga agar balok tidak melengkung tetapi diberi sentuhan keindahan ornamen dan warna. Semua itu terbuat dari karya ketukangan tangan dengan dibantu alat-alat yang sederhana. Hal ini tidak hanya trjadi di rumah pada umumnya tetapi di lngkungan kratonpun hal seperti in juga sama .

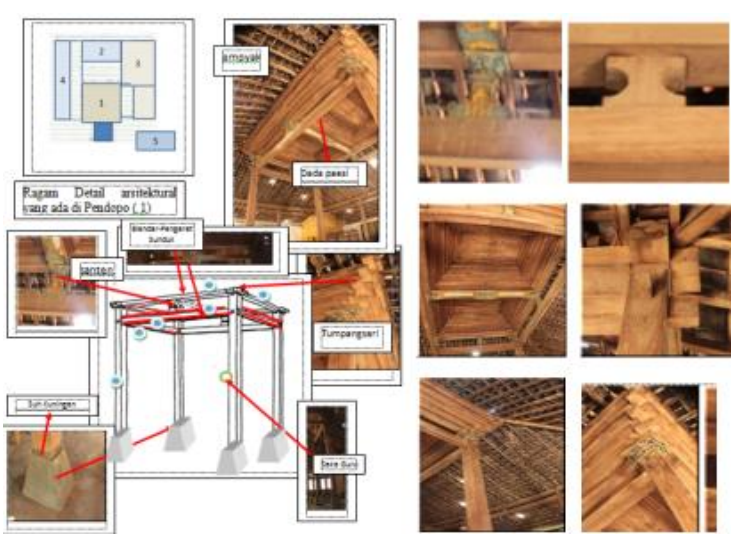

Gambar 5. Karya ketukanganan pada struktur konstruksi

Sumber: Hardiyati, 2015

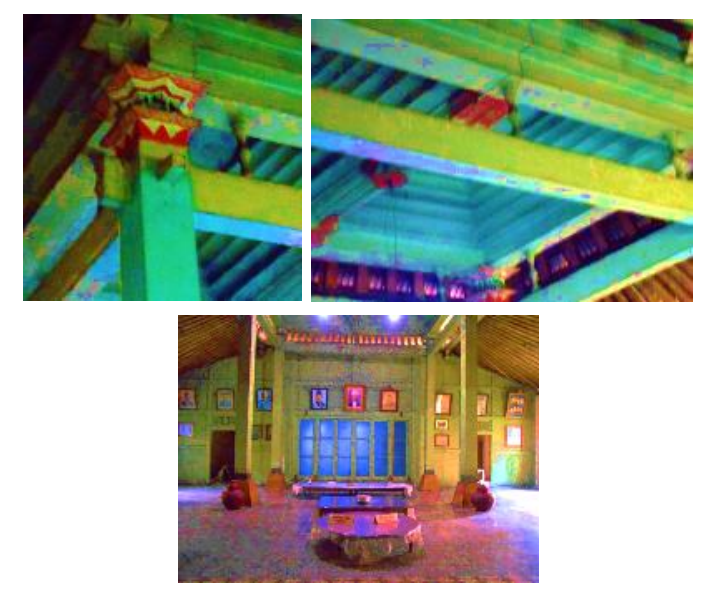

Gambar 6. Karya Ketukangan Pada strukturkonstruksiutama dindalem Mangubumen Surakarta.
Secara prinsip penggarapan ndalem pangeran juga dkerjakan oleh ketukangan tangan hanya biasanya bedanya adalah hanya pada kwalitas kayu yang dipakai dalam ndalem kraton akan memilik kwaitas kayu yang lebih baik dan penggarapan lebih halus. Tukang memliki kesadaran material yang sangat tinggi yang bersifat sangat natural dalam sebuah realita praxis dalam ruang dan waktu yang sangat spesifik. Pertukangan disini akan terlihat ada kaitan erat antara kerja praktis ketukangan , mausia tukang itu sendiri, karya ketukangan, alat yang dipakaidan pemkran akan berjalan begitu indahnya yaitu setara. Yang sering dalam kancah arsitektur peran tukang dan alat yang digunakan tdak pernah diperdengarkan dan dihadirkan. Pengerjaan 'ketukangan' ditata secara sekuensial menurut kwalitas kayu .

Kesadaran material dan ketukangan pada arsitektur jawa biasanya mengaju pada kawruh kalang yang menjadi rujukannya. material kayu dan bambu adalah material yang paling mendominasi dalam arsitektur jawa, sehingga ada kaitan erat antara potensi alam dankarya arsitektur jawa bisa menjadi cerita tektonis dan barangkali bisa menandai tingkat kepekaan ketukangan kriya pada arsitektur jawa yaitu pada material organik. Para tukang pada waktu itu masih memiliki kemerdekaan dalam berkarya karena tukang memiliki domnasi dalam pembuatan arsitektur jawa. Mereka memilki ketrampilan yang sangat terlatih. Para tukang memilik pengetahuan yang teraba dan tak teraba, kedua bentuk pengetahuan tersebut memiliki interaksi hubungan yang sangat kompleks. .

Pengetahuan teraba merupakan pengetahuan yang dapat dikomunikasikan dan diekspresikan dan bisa dipahamioleh orang lain seperti pengetahuan struktur konstruksi, material secara logis. Pengetahuan struktur konstruks sangat lejkat dengan pengetahuan material demikian juga diikutu dengan pengetahuan alat yang dipergunakan. Biasanya pengetahuan seperti ini saling ditularkan pada seluruh tukang yang bekerja bersama dengan latihan langsung dilapangan, sehingga kemahiran tukang akan terjadi dengan prosen latihan dan pengalaman ang terus menerus. Disamping secara teraba pengetahuan ini bisa dikomunikasikan para tukang juga memilki intuisi karena secara terus mengerjakan pekerjaan yang secara terus menerus langsung dilapangan sehingga terbangun pola berfikr dibawah sadarnya 
yang terbangun lewat sesuatu yang teraba, terlihat dan tak teraba yaitu rasa. Pada akhirnya pengetahuan teraba yang dibangun secara bersama-sama secara terus menerus akan menjadi pengetahuan kolektif dan menjadi tradisi membangun .

Karya kriya ketukangan pada arsitektur jawa yang bertolak dari kearifan tradisi dapat digunakan sebagai keunikan karya aritektur dalam keragaman karya arsitektur yang ada didunia,dan diharapkan bisa tumbuh secara natural . Pelaku ketukangan sekarang sudang tidak banyak , kelebihan dari ketukangan pada arsitektur jawa adalah memiliki peran kreator atau desainer sekaligus tenaga terampilnya . Biasanya tukang pada arsitektur jawa merupakan kerja atas dorongan kalbunya untuk menghadirkan sesuatu bangunan bagi orang-orang yang dihormatinya .

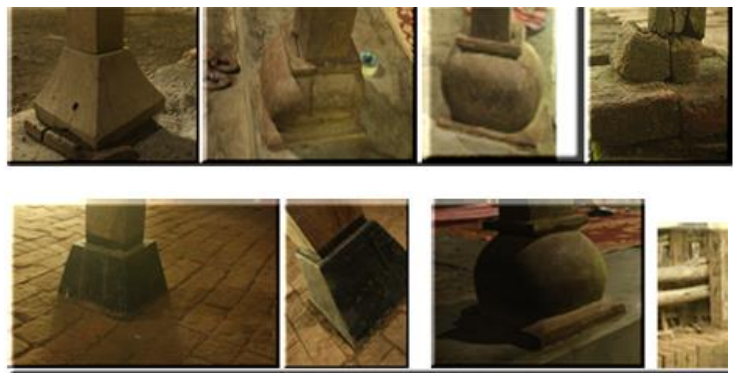

Gambar 7. ka rya ketukangan pada elemen struktur kontruksi Umpak

Karya ketukangan tangan dalam mewujudkan rumah jawa sangat eksploratif terhadap pemakaian dan pengolahan material. akan memunculkan bentuk-bentuk yang tidak sama karena dibuat dengan tangan sehingga bentuk bangunan sangat bervariatif dan inovatif walaupun dengan konsep yang sama. Teknologi dalam arsitektur yang digunakan para tukang kriya tangan adalah cara dimana dia menciptakan ide-ide metafora yang menempatkan mereka dalam alam melalui manipulasi bentuk dengan mengarahkan potensi alam. Dengan demikian teknologi arsitektur yang digunakan para tukang menyertakan pembentukan metafora berfikir tentang potensi/kekuatan alam. hal ini akan melengkapi bahwa bahwa teknogi selalu berorientasi hal yang selalu sifatnya terukur saja tetapi ada sesuatu yang lebih prinsipiil ada sesuatu yang esensi penting dalam lingkungan alam dan mulai memiliki muatan filosofis tentang sesuatu yang unik, spesifik dengan interpretasi yang bermakna pada lingkungan alam binaan seperti yang diungkapkan Vine, 2001.

\subsection{Material yang Digunakan untuk Kriya Ketukangan Arsitektur Jawa}

Dalam Tektonik Mangunwijaya, Mahatmanto (1999) Place-space-structure dan material merupakan suatu kontinum yang menciptakan tempat untuk ada. Manusia butuh ketegasan teritori suatu wilayah berhuni dengan mendirikan suatu struktur yang disusun melalui materil-material . Dengan demikian material merupakan titik tolak dalam proses mendirikan bangunan atau membangun. Teknologi kriya ketukangan mampu memanipulasi bahan dengan alat sederhananya telah menghasilkan karya yang khas seperti yang kita saksikan pada banyak bangunan rumah jawa .

Sebagai realitas karya ketukangan, arsitektur jawa merupakan karya masterpiece yang memiliki kemampuan mencitrakan dirinya. Jika dipandang dari berbagai aspek diantaranya aspek filosofis, kaidah-kaidah keseimbangan antara fungsi dan konstruksi, klimatologi, kepadatan pengguna dan area, bahan yang digunakan, proporsi, tampilan, garis tegas ornamen, sampai makna warna. Hal ini menunjukkan bahwa arsitektur Jawa menjadi produk kebudayaan yang sarat kearifan , bersifat objektif, dan karenanya teramati . Citra arsitektur rumah jawa terbentuk karena tidak terlepas dari potensi alam, sifat manusia penghuni dan masyarakatnya, yang menunjukkan keselarasan dengan alam sekelilingnya.

Material Kayu adalah material yang mendominasi dari bahan material struktur konstruksi rumah jawa di pedesaan yang dikerjakan dengan kriya ketukangan. Kayu merupakan bahan material bangunan yang sangat flexible, kayu masih banyak digunakan untuk bahan bangunan dinegeri manapun karena sebenarnyakayu merupakan bahan yang bisa terbarukan karena pohon-pohon bisa ditanam kembali. Kayu bisa digunakan baik dalam bahan struktur maupun bahan finishing baik penutup atap, dinding lantai dan lain pada elemen bangunan. Disamping kayu juga digunakan bahan alam lain yaitu bata dan batu serta bambu. Tetapi yang sangat dominan 
adalah material organik utamanya kayu, bambu, daun-daunan.

Kayu juga memiliki kesan estetis dari waku ke waktu karena setiap pohon bisa memiliki tekstur kayu yang tidak sama disamping kemampuan akhir untuk merekayasa dengan berbagai aplikasi. Kayu akan terkait dengan tempat-tempat dengan sumber alam hutan yang berlimpah atau juga menjadi tanaman rakyat rumah kayu sebenarnya merupakan rumah cerdas untuk masa depan. Bangunan kayu dapat dibangun dengan praktis, dengan ketrampilan masyarakat setempat dapat dibangun dengan cepat dan ilmu setempat. Kayu memiliki kehangatan yang dihasilkan dari warna dan tekstur bahan itu sendiri. Bangunan terbuat dari kayu sangat dipengaruhi oleh tradisi kerajinan.

Konstruksi kerangka ringan kayu (Alen, 1999) merupakan sistim yang paling luwes dibanding sistim bangunan lainnya. Jarang ada bentuk yang tidak dapat dibangun dengan konstruksi kayu, selama satu setengah abad lalu sejak konstruksi ini digunakan pengkerangkaan ringan kayu berfungsi untuk membuat bangunan-bangunan dengan gaya yang berkisar dari penginterpretasian ulang hampir seluruh mode historis hingga ke ekspresi tegas pada setiap Arsitektur abad 20.

Dengan menerapkan alat dan teknik yang tepat untuk sepotong kayu yang baik, imaginasi seorang kriya tukang kayu hanya dibatasi oleh sifat materinya, bahan material memiliki kehidupan sendiri, karena memiliki karakter yang khas. Pengetahuan ini merupakan prasarat yang diperlukan untuk pengolahan bahan yang tepat seperti apa yang dibahas Zwerger (2011). Kayu akan terkait dengan budaya woodworking.

Banyak jenis kayu yang digunakan pada rumah jawa masing-masig mempunyai sifat masing masing, karakter kayu tidak hanya terlihat dari apa yang hanya bisa kita lihat dan kita raba tetapi juga kita bau dan rasakan yang kadang sulit untuk disikripsikan yang akan memberi performa penampilan yang berbeda serta tujuan tertentu. Masing -masing kayu memiliki kualitas yang unik dan bisa disesuaikan dengan masing-masing penggunaan. Kesesuian spesies kayu tertentu akan berkaitan dengan kemudahan kerja struktur-konstruksi, daya tahan, ketersediaan, stabilitas, ketahanan terhadap deformasi. Spesies kayu yang tersedia dapat menjadi kriteria untuk seleksi, karena pengetahuan tentang sifat dari jenis kayu akan mengarahkan pada pemilihan jenis konstruksi dan tukang mampu melakukan semua itu.

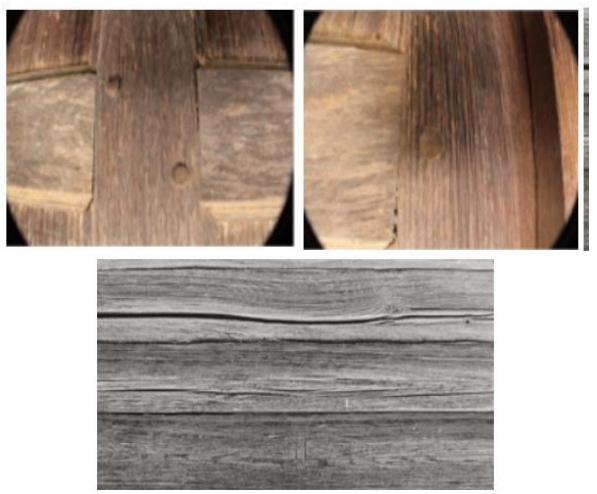

Gambar 8. Kayu mampu memunculkan berbagai tampilan

Selama periode panjang manusia tidak dipaksa untuk menghuni tempat huniannya secara permanen, manusia diberi kesempatan mengumpulkan kesan dan pengalaman untuk kesesuaian berbagai spesies kayu yang tersedia. Pada awalnya manusia sudah dekat dengan temuan archeologi tangan dan menyebarkan atau mengkomunikasikan berbagai spesies kayu menjadi sebuah bangunan huniannya.

Penggunaan material utamanya ditentukan oleh ketersediaan, tukang kayu belajar dari nenek moyang kita yang terdorong mencari bahan bangunan yang ada disekitar kita yang juga mampu untuk mereka mengerjakan. Kayu yang tersedia cukup banyak dengan sendirinya menjadi sebuah pilihan ideal untuk kemudahan kerjanya. Dengan pengalaman menangani kayu, pemilihan tidak hanya sebatas jenis kayu tetapi sampai bentuk potongan-potongan kayu. Alam banyak memberi bantuan setiap saat ,manusia semakin tergantung dengan alam sehingga manusia selalu berusaha untuk kompatibel dengan alam. Membangun dengan kayu didasarkan linier atau konsep anatomi tumbuhan hal tersebut sesuai dengan struktur kayu itu sendiri, mereka memiliki kemampuan setiap potong kayu tidak hanya rekayasa secara cerdik tetapi juga menciptakan estetika ini merupakan bukti bahwa merupakan kriya ketukangan pada arsitektur jawa pengetahuan bahan bekerja bersama-sama dengan berfantasi dengan alam. 


\subsection{Kriya Ketukangan dan Alat pertukangan}

Keragaman rumah-rumah jawa yang luar biasa banyak ini mengindikatorkan bahwa kebutuhan masing-masing individu memiliki kebutuhan yang berbeda yang terlihat dari eksterior dan interior itu merupakan cerminan akumulasi pengalaman para tukang kayu. Mayoritas petani /masyarakat tidak berada dalam posisi menunjuk orang lain untuk membangun rumah mereka, mengandalkan bahan yang tersedia, penggunaan kadang masih subyektif dengan berbagai keterbatasan yang amat sangat, batuan dari lingkungan sanak keluarga, desain yang optimal berkembang yang sebenarnya menimbulkan sebuah kerinduan yang luar biasa.

Sampai saat ini khususnya daerah pedesaan yang masih bisa ditanam kayu tersedia kesan seperti ini masih bisa kita tangkap , pengetahuan membangun dan alat yang digunakan yang dimiliki adalah turunan /warisan dari pendahulunya. Fungsi ditambah dengan keunikan yang terjadi melalui penggunaan bahan-bahan alami menentukan daya tarik tersendiri, tampaknya sangat sederhana demikian dengan strukturnya, telah diterima secara komunitas Sering kita melihat bangunan menjadi terlalu kecil tetapi tak ada yang berfikir untuk memperbesarnya.

Pengalaman adalah sebuah prinsip keberhasilan pekerjaan tukang kayu, pengalaman tersebut hanya dapat diperoleh melalui kerjasama dengan material setiap hari, setahap demi setahap selalu dicari pemecahan setiap masalah yang ditemuinya secara keseluruhan baik metoda proses, alat dan kreatifitas. Pengalaman membuat sebuah pekerjaan lebih mudah dan menjadi sebuah keniscayaan dari memilih kayu, menempatkan pada bagian tertentu, bentuk sendi yang paling tepat sehingga bentuk secara keseluruhan terwujud semua pekerjaan pertukangan adalah pemahaman tapi juga diikuti sebuah intuisi yang dimiliki setiap tukang yang mengerjakan yang sifatnya tidak terukur tapi dapat terlihat nyata hasilnya.

Alat pertukangan yang dipergunakan pada sebuah tempat masing-masing tidak sama tergantung kebutuhan, kadang tukang kayu ngotak-atik alat sesuai dengan kebutuhan.
Alat-alat yang fungsional diperluas peruntukannya untuk alat craft misalnya dengan memperuncing atau memperpendek alat tertentu. Alat yang digunakan adalah pahat, pasah, alat pengukur, penjepit yang ini menunjukkan kepada kita modal seorang carpenter alat sebagai investasi, dan alat-alat itu sampai sekarang masih dipergunakan .
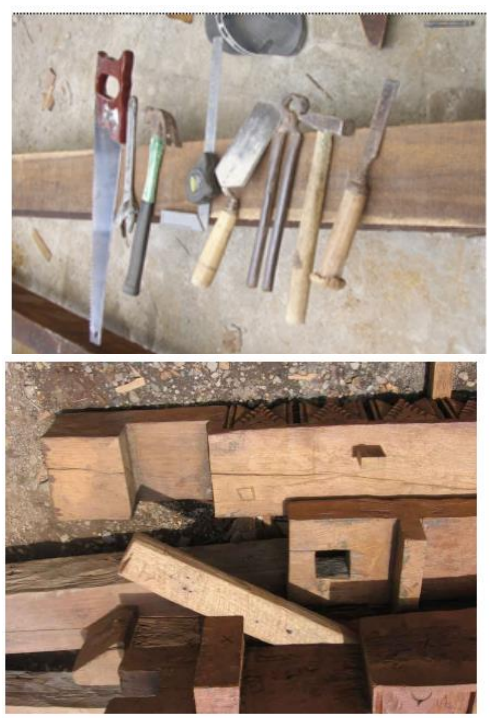

Gambar 9. Alat-alat pertukangan dan hasil pekerjaan kayu dengan a lat-alat pertukangan

Inovasi dalam mengembangkan peralatan tersebut secara empiris berdasar naluri dan pengalamannya. teknologi lokal seperti ini sering menampilkan "kriya" dan "seni". Hal ini disebabkan karena para tukang lebih bebas untuk mencoba atau bereksperimen, tradisi menjadi inspirasi kreatifitasnya ini terlihat dari ragam wujud berbagai elemen-elemen bangunan rumah jawa yang dihasilkan dari karya kriya ketukangan tangan yang masih bisa kita saksikan sampai hari ini

\subsection{Kreatifitas Ketukangan pada Elemen- Elemen Non Konstruktif dan Konstruktif}

Sambungan Kayu Sebagai Ekspresi Nilai Estetika Sambungan kayu dibuat karena memiliki fungsi yang harus dipenuhi, kriteria estetika berperan sekunder dalam pembentukan sambungan. Utama dalam pembentukan bangunan memberikan suatu elemen konstruksi yang bersifat penting, para tukang memiliki kreatifitas untuk menambahkan menjadi elemen estetika dimana 
keindahan - kecantikan dari setiap elemen yang dihasilkan bukanlah tujuan utama itu sendiri. Kecantikan menempati urutan kedua dari fungsi. Para tukang memiliki pemikiran keindahan elemen bangunan harus memiliki tujuan sehingga katagori indah dan berguna melebur menjadi satu kesatuan relasi.

Keindahan elemen-elemen sungguh luar biasa sangat dicirikan oleh bahan bakunya sendiri. Jumlah dari propertinya dapat digunakan secara estetis . Perbedaan antara dua potong kayu adalah diukur dengan perbedaan properti mereka, tukang kayu memperhitungkan individu sifat material yang akan dikerjakan, dengan dibantu dengan alat ketukangan sederhana menampilkan keindahan tanpa merampok dari karakteristik dari sifat material nya itu sendiri hanya untuk memuaskan diri sendiri, pertimbangan itulah pertimbangan yang sangat luar biasa .

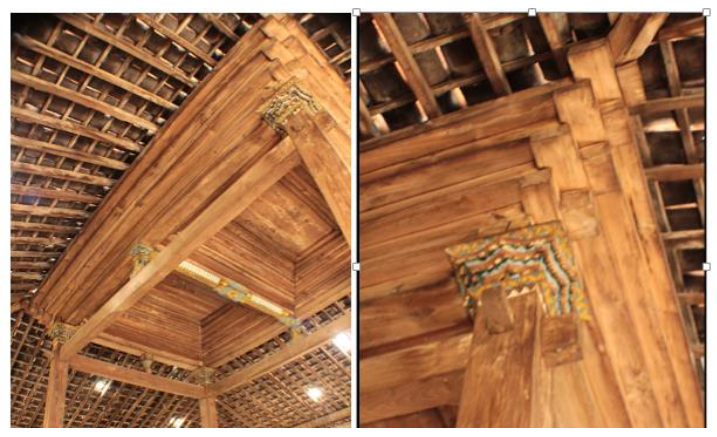

Gambar 10. Elemen-elemen konstruktif yang memunculkan estetika

Sambungan, sebagai komponen arsitektur terkecil, adalah salah satunya indikator yang paling terlihat dari konsep dari awalnya bersifat konstruktif bergeser mampu menimbulkan keindahan- kecantikan. Peran dari setiap komponen yang direkayasa menjadi lebih luas skalanya untuk menawarkan ekspresi keindahan . Sambungan kayu juga merupakan ekspresi penghormatan yang tinggi terhadap bahan kerja. Para tukang telah melakukan intervensi dalam siklus hidup alam dengan menebang pohon. Sekarang umat manusia harus melakukan yang terbaik untuk menangani bahannya secermat mungkin dan melakukan yang terbaik untuk melestarikannya dengan penggunan yang sangat hati-hati.

Para tukang kayu telah memiliki pemikiran bagaimana penggunaan material kayu yang optimal dan efisien dan pemikiran itu ada di latar depan. Kayu solid dengan kualitas terpilih telah menjadi simbol status. Itu terlihat kalau di bangunan jawa kayu yang paling bagus berkedudukan di inti bangunan soko guru tumpangsari dan seluruh perangkatnya dan seterusnya simbol struktur tersebut diikuti simbol keindahan yang dipancarkannya. Sebagai jurang pemisah antara hidup dengan alam dan hidup di alam semesta tumbuh lebih luas, selama sumber daya tersedia dalam jumlah yang banyak, masalah struktural diselesaikan sejalan dengan pengalaman dan penilaian estetika yang ditentukan oleh tradisi juga lebih leluasa.

Sambungan kayu menjadi kendaraan tukang kayu untuk gagasan artistik, sarana mengungkapkan nilai subjektif dan obyektif. Ini tidak hanya tidak independen satu sama lain tetapi, terus terang, saling terkait dan saling tergantung. Pengaruh yang membentuk sambungan kayu tukang kayu individu bergantung pada "tujuan" fungsional dan estetika ideal sejauh mampu disatukan. Estetika dipengaruhi dan dikembangkan oleh gagasan "subyektif" keindahan masing-masing pengrajin meskipun dengan langkah-langkah kecil. "Pengrajin" memang cenderung sangat konservatif hal ini dikarenakan pada waktu itu mereka tidak memiliki kesempatan untuk keluar dari lingkungannya untuk memperluas wawasannya demikian mental inspirasinya didorong dari tugas-tugas barunya, semakin banyak bangunan yang diselesaikan intuisi semakin baik.

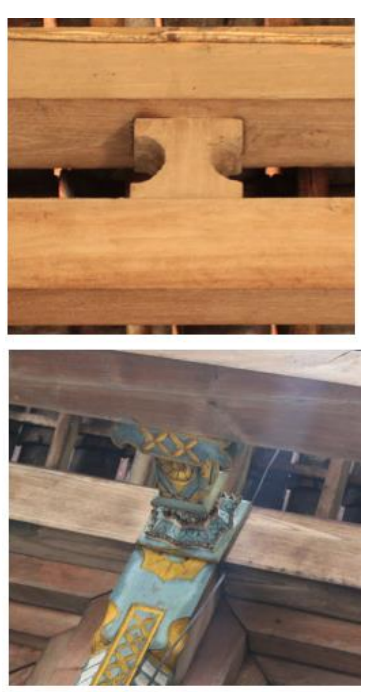

Gambar 11.Elemen yang memiliki peran sama mendapat perlakuan y ang berbeda di-hira rkikan pada penempatannya 
Kriya ketukangan pada elemen-elemen non konstruktif lebih bebas dalam kreatifitasnya. kreatifitas tidak muncul secara tiba-tiba melainkan sebuah proses panjang pencarian, proses coba-coba, kreatifitas dalam desain arsitektur adalah proses "pencarian, posisi proses sederajat dengan hasil.
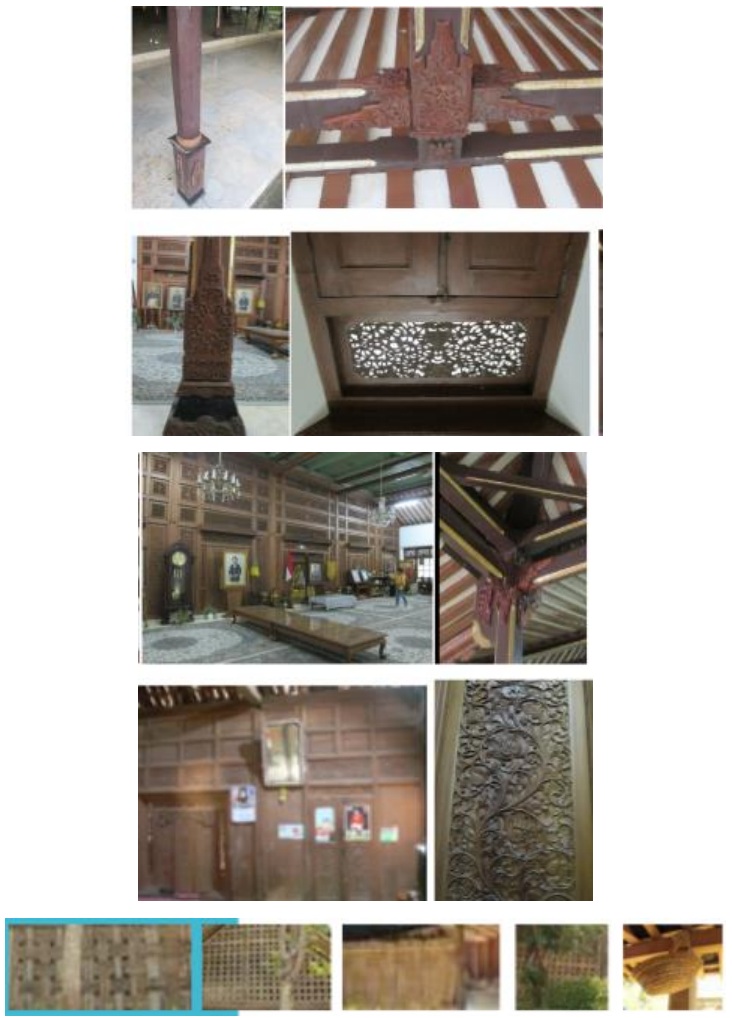

Gambar 12. Ka rya kriya ketukangan mampu memunculkan berbagai artikulasi.

\section{KESIMPILAN}

Perjalanan dan perkembangan peradapan manusia telah menghadirkan berbagai ragam medianya, dimulai dari penggunaan bahanbahan yang alami, bahan yang belum mengalami perubahan seperti batu-kayu seperti apa adanya ketika ditemui di alam. Selanjutnya oleh ketukangan dibuat untuk wujud-wujud yang dikehendaki. Wujud-wujud tersebut merupakan ungkapan tulen/orisinal tanpa padanan /preseden sebelumnya. Kita perlu memahami mekanisme dan segala kaitmengkait ekspresi-ekspresinya. Langkah pemikiran seperti inilah manusia memungkinkan menyeberang dari satu dunia ke dunia lainnya. Dengan demikian manusia pandai berbahasa dalam arti luas kemudian mulai mengembangkan kemampuannya, manusia menghadapi dunia tanpa batas dunia idea yang penuh misteri. Yang pada akhirnya manusia sampai pada material tiruan yang ada di alam, yang memungkinkan ungkapan baru. Rangkaian sejarah perkembangan arsitektur bisa dipakai untuk menggambarkan kecenderungannya.

Kriya ketukangan karya tangan pada arsitektur Jawa yang sarat dengan kearifan lokal bisa dilestarikan dengan cara memakainya, bukan hanya pengetahuan yang terlihat tangible yang perlu dilestarikan, pengetahuan yang intangible pun perlu dipelihara. Persoalannya bagaimana memelihara ketrampilan kriya ketukangan itu. Dalam dunia yang telah dibanjiri oleh mesin hal ini akan menjadi ancaman yang serius bagi kelangsungan keberadaannya kriya ketukangan tersebut banyak hal terancam komodifikasi dalam arsitektur. Dalam arsitektur komodikatif detail-detail konstruksi menjadi elemen-elem yang tampil dengan mahal. dan apabila ada kriya-ketukangan adan dipandang "ndesani" bagi kacamata kehidupan sekarang.

Dengan demikian kriyawan harus selalu memiliki kreatifitas dalam menanggapi perubahan jaman dengan saling mendukung, berkolaborasi dalam menciptakan karya harus memiliki pengetahuan, kemampuan, ketrampilan, peka secara rupa sejalan dengan teknologi, konsep originalitas dalam berbagai media . Disamping itu perlu juga mampu menangkap peluang karya kriya secara fungsional, ekonomi dan sosial budaya.

Karya kriya ketukangan pada arsitektur Jawa mampu memberi keseimbangan dan harmoni manusia alam dan budaya, kelestarian dan keragaman kultur, konservasi sumber daya alam dan warisan budaya, hemat sumber daya. Disamping itu Kriya ketukangan mampu memberi artikulasi proses pembuatan, artikulasi bakat/karakter bahan, artikulasi ekspresi beban sambungan artikulasi permainan pengolahan bahan. 


\section{REFERENSI}

IAI,2024, Ketukangan Kesadaran Material Craftmanship Material Consciousness, Ikatan Arsitektur Indonesia (IAI) Jakarta Alenn G Noble, 2007, Traditional Buildings a Global Survey of Structural Form and Cultural Fungtion, I.B.Tauris \& Co Ltd, London

Groat, L. \& Wang, D. Architectural Research Methods. New York: John Wiley \& Sons.2002.

Lance La Vine,2001, Mechanics and meaning in Architecture, university of minnesota Press Minneapolis, London

Mahatmanto, 1999, The TectonicArchitecture YB MANGUNWIJYA, Rumah Cemeti Yogyakarta

Pangarsa, Galih Widjil .2006, Merah Putih Arsitektur Nusantara, Andi OfsetYogyakarta

Prijotomo, Josef., 2006. Re-Konstruksi Arsitektur Jawa, Griya Jawa Dalam Tradisi Tanpa Tulisan, Wastu Grafika Surabaya

Raharjo,Timbul, 2016, Pameran Seni Kriya Undagi, Dirjen Kesesnian Direktorat Jendral Kebudayaan Kementerian Pendidikan Dan Kebudayaan Indonesia

Ronald, Arya .2005, Nilai-Nilai Arsitektur Rumah Tradisional Jawa, Gadjah Mada University Press.

Ronald, Arya. 1997, Ciri Ciri Karya Budaya Dibalik Takbir Keagungan Rumah Jawa , Atmajaya Yogyakarta. Sennett, Richard,2008, The Craftsman, yale university press new haven \& london

Zwerger, Klaus ,2011, Wood and Wood Joins Building Tradition of Europe, Japan and China, Birhauser Basel Switzerland. 